\title{
Dairy Farm Effluent Effects on Urine Patch Nitrous Oxide and Carbon Dioxide Emissions
}

\author{
Tim J. Clough* and Francis M. Kelliher
}

\begin{abstract}
Dairy farm effluent (DFE) comprises animal feces, urine, and washdown water collected at the milking shed. This is collected daily during the milking season and sprayed onto grazed dairy pastures. Urine patches in grazed pastures make a significant contribution to anthropogenic $\mathrm{N}_{2} \mathrm{O}$ emissions. The DFE could potentially mitigate $\mathrm{N}_{2} \mathrm{O}$ emissions by influencing the $\mathrm{N}_{2} \mathrm{O}$ to dinitrogen $\left(\mathrm{N}_{2}\right)$ ratio, since it contains water-soluble carbon (WSC). Alternatively, DFE may enhance $\mathrm{N}_{2} \mathrm{O}$ emissions from urine patches. The application of DFE may also provide a substrate for the production of $\mathrm{CO}_{2}$ in pasture soils. The effects of DFE on the $\mathrm{CO}_{2}$ and $\mathrm{N}_{2} \mathrm{O}$ emissions from urine patches are unknown. Thus a laboratory experiment was performed where repeated DFE applications were made to repacked soil cores. Dairy farm effluent was applied at 0,7 , or $14 \mathrm{~d}$ after urine deposition. The urine was applied once on Day 0 . Urine contained ${ }^{15} \mathrm{~N}$-enriched urea. Measurements of $\mathrm{N}_{2} \mathrm{O}, \mathrm{N}_{2}$, and carbon dioxide $\left(\mathrm{CO}_{2}\right)$ fluxes, soil $\mathrm{pH}$, and soil inorganic $\mathrm{N}$ concentrations were made. After $43 \mathrm{~d}$ the DFE had not mitigated $\mathrm{N}_{2} \mathrm{O}$ fluxes from urine patches. A small increase in the $\mathrm{N}_{2} \mathrm{O}$ flux occurred from the urine-treated soils where DFE was applied 1 wk after urine deposition. The amount of WSC applied in the DFE proved to be insignificant compared with the amount of soil $\mathrm{C}$ released as $\mathrm{CO}_{2}$ following urine application. The priming of soil $\mathrm{C}$ in urine patches has implications for the understanding of soil $\mathrm{C}$ processes in grazed pasture ecosystems and the budgeting of $\mathrm{C}$ within these ecosystems.
\end{abstract}

$\mathrm{D}$ UE TO ITS DUAL ROLE as a greenhouse gas (Duxbury et al., 1993) and as a precursor to ozone-depleting gases (Crutzen, 1981) there is interest in mitigating the emissions of nitrous oxide $\left(\mathrm{N}_{2} \mathrm{O}\right)$. Agricultural soils are a major source of anthropogenic $\mathrm{N}_{2} \mathrm{O}$ (Food and Agriculture Organization of the United Nations, 2001) and intensive grazing systems have relatively high emissions of $\mathrm{N}_{2} \mathrm{O}$ compared with cropping systems. For $\mathrm{N}_{2} \mathrm{O}$ mitigation strategies to be adopted they must be economical, easily applied to existing farming methods, and/or require minimal disruption to existing practices. In New Zealand, legislation prevents the direct discharge of DFE to surface waters and current farming practice consists of applying the DFE to pasture soils. Dairy farm effluent is collected at the milking shed. Animal effluent is deposited in the concrete yard area as animals wait to be milked and during milking. The yard is washed down after milking, with the wash-down water and effluent gravity-fed into tanks where pumps then empty the DFE from the tanks by spray irrigating nearby pasture. The predominant constituents of the DFE are urine and dung. Dairy

T.J. Clough, Soil, Plant and Ecological Sciences Division, PO Box 84, Lincoln University, Canterbury, New Zealand. F.M. Kelliher, Landcare Research, PO Box 69, Lincoln Canterbury, New Zealand. Received 21 Sept. 2004. Technical Reports. *Corresponding author (clought@lincoln.ac.nz).

Published in J. Environ. Qual. 34:979-986 (2005).

doi:10.2134/jeq2004.0360

(c) ASA, CSSA, SSSA

677 S. Segoe Rd., Madison, WI 53711 USA farm effluent composition varies according to animal numbers, feed quality, and volume of wash-down water. Dairy farm effluent contains nitrogen $(\mathrm{N})$ as urea, ammonium $\left(\mathrm{NH}_{4}^{+}\right)$, nitrate $\left(\mathrm{NO}_{3}^{-}\right)$, and organic $\mathrm{N}$ forms. The total $\mathrm{N}$ content of DFE varies but reported values range from 260 to $280 \mathrm{mg} \mathrm{N} \mathrm{L}^{-1}$ (Barton and Schipper, 2001; Di and Cameron, 2004). The C content of DFE also varies with feed quality. Barton and Schipper (2001) found DFE from pasture-fed animals had a total C content of $0.2 \%$, a dry matter content of $0.4 \%$, and a $\mathrm{pH}$ of 7.9. Nitrogen application rates of DFE to pasture thus depend on its composition and the volume of irrigation. The timing of DFE application also varies with respect to the time of urine deposition and the resulting urine patches. Dairy farm effluent may be applied immediately after grazing or several days after grazing depending on the grazing rotation employed on the farm and the DFE application strategy. It is also feasible that a urine patch may receive repeat applications of DFE.

Nitrous oxide emissions can be promoted by DFE application to pastures. Barton and Schipper (2001) found DFE irrigation to be a source of $\mathrm{N}_{2} \mathrm{O}$ due to increases in soil $\mathrm{N}$, water content, and available $\mathrm{C}$ when DFE was applied to peat and mineral soils. However, the study of Barton and Schipper (2001) did not examine the potential relationship between $\mathrm{N}_{2} \mathrm{O}$ and dinitrogen $\left(\mathrm{N}_{2}\right)$ fluxes or the possible effect of repeated applications of DFE. The deposition of bovine urine $\mathrm{N}$ onto pasture soils also stimulates $\mathrm{N}_{2} \mathrm{O}$ emissions. The availability of watersoluble carbon (WSC) can influence denitrification rates and/or the ratio of $\mathrm{N}_{2} \mathrm{O}$ to $\mathrm{N}_{2}$ (Burford and Bremner, 1975; Firestone, 1982). Priming effects are short-term changes in the turnover of soil organic matter where large amounts of $\mathrm{C}, \mathrm{N}$, and other nutrients may be released or immobilized in a very short time (Kuzyakov et al., 2000). Urine addition to soils can result in increases in $\mathrm{CO}_{2}$ fluxes, over and above the amounts of $\mathrm{C}$ applied, with the release of native soil $\mathrm{C}$ indicative of a priming effect (Clough et al., 2003). The interaction of DFE and urine patches, with respect to $\mathrm{N}_{2} \mathrm{O}$ emissions, has not been reported on. It is possible that DFE application to urine patches (i) increases $\mathrm{N}_{2} \mathrm{O}$ emissions from urine patches due to the addition of extra $\mathrm{N}$ substrate and nutrients or (ii) alters the ratio of $\mathrm{N}_{2} \mathrm{O}$ to $\mathrm{N}_{2}$ due to the addition of $\mathrm{C}$ and irrigation water creating conditions conducive to the further reduction of $\mathrm{N}_{2} \mathrm{O}$. The objectives of this study were to assess the effects of DFE on urine patch $\mathrm{N}_{2} \mathrm{O}, \mathrm{N}_{2}$, and $\mathrm{CO}_{2}$ emissions.

\section{MATERIALS AND METHODS}

\section{Soil and Treatments}

A Temuka silt loam soil [Fluvaquentic Endoaquept; Soil Survey Staff (1998)] was collected from a $2-\mathrm{m}^{2}$ area of a dairy

Abbreviations: DFE, dairy farm effluent; WFPS, water-filled pore space; WSC, water-soluble carbon. 
Table 1. Timing of dairy farm effluent (DFE) treatment applications and total rates of inorganic $\mathbf{N}$ and water-soluble carbon (WSC) applied in the DFE treatments. The control and urine treatments did not receive DFE.

\begin{tabular}{|c|c|c|c|c|c|c|c|}
\hline \multirow[b]{2}{*}{ Treatment $\dagger$} & \multicolumn{5}{|c|}{ Day } & \multirow[b]{2}{*}{ Inorganic $\mathbf{N}$} & \multirow[b]{2}{*}{ WSC } \\
\hline & $\mathbf{0}$ & 7 & 14 & 21 & 28 & & \\
\hline & & & & & & - kg ha & 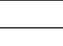 \\
\hline DFE & $\checkmark$ & $\checkmark$ & $\checkmark$ & & & 1.5 & \\
\hline UDFE0 & $\checkmark$ & $\checkmark$ & 4 & & & 1.5 & $\begin{array}{l}49 \\
29\end{array}$ \\
\hline $\begin{array}{l}\text { UDFE1 } \\
\text { UDFE2 }\end{array}$ & & $\checkmark$ & $\begin{array}{l}\checkmark \\
\checkmark\end{array}$ & $\checkmark$ & $\checkmark$ & $\begin{array}{l}4.0 \\
3.6\end{array}$ & $\begin{array}{l}29 \\
47\end{array}$ \\
\hline
\end{tabular}

$\dagger$ Urine was applied on Day 0 in all of the DFE treatments. DFE applications, indicated by the symbol $\checkmark$, commenced on Days 0,7 , and 14 for treatments UDFE0, UDFE1, and UDFE2, respectively.

farm pasture, at a 0 - to $10-\mathrm{cm}$ depth $\left(43^{\circ} 38.70^{\prime} \mathrm{S}, 172^{\circ} 28.62^{\prime} \mathrm{E}\right.$; $8 \mathrm{~m}$ above mean sea level). The soil bulk density in situ averaged ( \pm standard error mean) $0.76 \pm 0.06 \mathrm{Mg} \mathrm{m}^{-3}$. The soil had a $\mathrm{pH}_{\text {(water) }}$, loss on ignition, $\mathrm{C}$, and $\mathrm{N}$ contents of $5.6,16.0 \%$, $7.3 \%$, and $0.7 \%$, respectively. Pasture species were principally perennial ryegrass (Lolium perenne L.) and white clover (Trifolium repens $\mathrm{L}$.). This pasture had a history of more than $50 \mathrm{yr}$ of intensive dairying but had not previously received DFE.

The soil was air-dried, sieved $(<0.4 \mathrm{~cm})$, and then repacked into PVC cylinders (8.3-cm i.d. by $7.5 \mathrm{~cm}$ deep) to a bulk density of $0.77 \mathrm{Mg} \mathrm{m}^{-3}$. These soil cores were then placed on tension tables as described in Clough et al. (2004), with suction applied using a hanging column of water $(-5.0 \mathrm{~cm}$ from the base of the soil cores), and allowed to equilibrate at this moisture content for $2 \mathrm{wk}$ (75\% water-filled pore space, WFPS).

The first set of soil cores, subsequently referred to as "Group 1," consisted of four treatments: a control, DFE, urine, and a urine + DFE treatment where DFE applications commenced on the same day as urine application (UDFE0). The DFE applications were applied on three occasions, at 7-d intervals (Table 1). Treatments were replicated thrice with four destructive sampling times, giving 48 cores in total for the Group 1 soil cores. Group 1 soil cores were used to determine changes in soil inorganic $\mathrm{N}$ concentrations over time, as described below. Dairy farm effluent composition and application rates, along with the rate of urine $\mathrm{N}$ in the treatments, are also noted below. A second set of soil cores, subsequently referred to as "Group 2," was comprised of four replicates by six treatments, 24 cores in total. The six treatments were a control, DFE, urine, UDFE0, UDFE1, and UDFE2. The UDFE1 and UDFE2 treatments consisted of urine + DFE with DFE applications commencing 7 and $14 \mathrm{~d}$ after urine application, respectively. Again, for all treatments receiving DFE, the application of the DFE occurred on three occasions, with each application $7 \mathrm{~d}$ apart (Table 1). The Group 2 soil cores were used to measure soil $\mathrm{N}_{2} \mathrm{O}$ and $\mathrm{N}_{2}$ fluxes, soil $\mathrm{pH}, \mathrm{CO}_{2}$ fluxes, WSC, and inorganic $\mathrm{N}$ as described below.

Urine applications consisted of synthetic urine, formulated according to Fraser et al. (1994), and were applied at the conservative rate of $500 \mathrm{~kg} \mathrm{~N}^{-1}$. In the Group 1 soil cores, the urine $\mathrm{N}$ applied was not enriched with ${ }^{15} \mathrm{~N}$ (i.e., it was at a natural abundance level of ${ }^{15} \mathrm{~N}$ ). In the Group 2 soil cores, the urea $\mathrm{N}$, in the urine applied, had a ${ }^{15} \mathrm{~N}$ enrichment of 40 atom $\%$ excess relative to ambient air. This was to enable the determination of the ${ }^{15} \mathrm{~N}$ enrichment in the $\mathrm{N}_{2} \mathrm{O}$ and $\mathrm{N}_{2}$ gas fluxes. The synthetic urine also contained $\mathrm{C}$ as: urea $\mathrm{C}(106 \mathrm{mg}$ core $\left.^{-1}\right)$, glycine $\mathrm{C}$ (39 $\mathrm{mg}$ core $\left.{ }^{-1}\right)$, and potassium bicarbonate (70 $\mathrm{mg}$ core $\left.^{-1}\right)$. The rate of DFE was determined on a volume basis, $0.025 \mathrm{~L}$ per soil core (equivalent to 0.09 pore volumes), to represent $5 \mathrm{~mm}$ of DFE irrigation. This provided the equivalent of 2 to $4 \mathrm{~kg}$ inorganic $\mathrm{N} \mathrm{ha}^{-1}$ and 29 to $49 \mathrm{~kg} \mathrm{WSC} \mathrm{ha}^{-1}$ (Table 1). Dairy farm effluent was applied fresh from the Lincoln University dairy shed at each application date. The original intention was to keep the DFE composition identical throughout the experiment by collecting and freezing the DFE, followed by thawing before its application. However, a test showed that DFE inorganic $\mathrm{N}$ concentrations changed after freezing, with $\mathrm{NH}_{4}^{+}$and $\mathrm{NO}_{3}^{-}$concentrations increasing and decreasing, respectively. The effect of freezing DFE on its microbial populations was also unknown. Thus DFE was collected and applied fresh at each application date. The inorganic $\mathrm{N}$ concentrations, WSC, and the $\mathrm{pH}$ of the DFE applied are shown in Table 2. As might be expected, the DFE constituents and $\mathrm{pH}$ differ slightly due to factors noted above. The dry matter content of the DFE was $<1 \%$. The soil cores were maintained at $20^{\circ} \mathrm{C}$ for the duration of the experiment.

\section{Measurements}

Soil surface $\mathrm{N}_{2} \mathrm{O}$ and $\mathrm{N}_{2}$ fluxes were measured from the Group 2 soil cores on 10 occasions over the 43-d period of the experiment. To facilitate headspace sampling, a gas-tight screw-on PVC lid containing a rubber o-ring was fitted creating an 81-mL headspace. Gas samples were taken $3 \mathrm{~h}$ after lid closure via a septum in the lid. Samples were obtained using a gas-tight syringe (SGE, Austin, TX) fitted with a push button valve and were transferred to $12-\mathrm{mL}$ vials (Exetainer tubes; Labco, High Wycombe, UK). The lids were then removed from the soil cores. Gas samples were analyzed for $\mathrm{N}_{2} \mathrm{O}$ and $\mathrm{N}_{2}$ on a continuous flow isotope ratio mass spectrometer (PDZ-Europa, Crewe, UK) using the methods of Stevens et al. (1993). The ${ }^{15} \mathrm{~N}$ enrichment of the $\mathrm{N}_{2}$ gas (atom $\%{ }^{15} \mathrm{~N}$ ) and the percentage $\mathrm{N}_{2}$ in the headspace were used to calculate an $\mathrm{N}_{2}-{ }^{15} \mathrm{~N}$ flux. The flux of ${ }^{15} \mathrm{~N}$ labeled $\mathrm{N}_{2} \mathrm{O}$ was calculated from its concentration and the enrichment of the $\mathrm{N}_{2} \mathrm{O}$ (atom \% $\left.{ }^{15} \mathrm{~N}\right)$. The flux ratio of $\mathrm{N}_{2} \mathrm{O}-{ }^{15} \mathrm{~N}$ to $\left(\mathrm{N}_{2} \mathrm{O}-{ }^{15} \mathrm{~N}+\mathrm{N}_{2}-{ }^{15} \mathrm{~N}\right)$ was also determined.

Throughout the experiment subsets of the Group 1 soil cores were destructively sampled for soil inorganic $\mathrm{N}$ concentrations at 1 -wk intervals. Group 2 soil cores were destructively sampled on Day 43. A subsample of soil was extracted (10 g dry soil to $100 \mathrm{~mL}$ of $2 \mathrm{M} \mathrm{KCl}$ ), shaken for $1 \mathrm{~h}$, filtered, and analyzed for inorganic $\mathrm{N}$ using a flow-injection analyzer

Table 2. Mean composition of dairy farm effluent (DFE) at each application. Twenty-five milliliters of DFE was applied per core at each application.

\begin{tabular}{|c|c|c|c|c|c|c|c|}
\hline \multirow{2}{*}{$\begin{array}{l}\text { Application } \\
\text { time }\end{array}$} & \multirow[b]{2}{*}{ pH } & \multirow[b]{2}{*}{$\mathbf{N H}_{4}^{+}-\mathbf{N}$} & \multirow[b]{2}{*}{$\mathbf{N O}_{3}^{-}-\mathbf{N}$} & \multirow[b]{2}{*}{$\mathbf{N O}_{2}^{-}-\mathbf{N}$} & \multicolumn{3}{|c|}{ Water-soluble carbon (WSC) } \\
\hline & & & & & Total & Inorganic & Organic \\
\hline \multicolumn{8}{|c|}{$\mu \mathbf{g} \mathbf{m} \mathbf{L}^{-1}$} \\
\hline 1 (fresh) & $8.1(0) \dagger$ & $8(0)$ & $2(0)$ & $0.1(0)$ & $466(4)$ & 45 (1) & $421(3)$ \\
\hline 7 & $7.8(0)$ & 15 (0) & $1(0)$ & $0.2(0)$ & 444 (5) & 30 (1) & 414 (5) \\
\hline 14 & $8.7(0)$ & $6(0)$ & 0 & 0 & 153 (8) & 52 (1) & 101 (8) \\
\hline 21 & $8.1(0)$ & 64 (1) & 0 & 0 & 454 (16) & 118 (1) & 336 (16) \\
\hline 28 & $8.0(0)$ & $7(0)$ & 0 & 0 & 400 (8) & 38 (2) & $362(8)$ \\
\hline
\end{tabular}

$\dagger$ Numbers in parentheses are standard deviations of the means, $n=5$. 
(Model FS3000; Tecator and Alpkem, Saskatoon, SK, Canada). Inorganic $\mathrm{N}$ concentrations in the Group 2 soil cores were determined in an identical manner after $43 \mathrm{~d}$. At this time the WSC content of the soil in the second set of soil cores was also determined according to the method used by Burford and Bremner (1975). Total, organic, and inorganic WSC were measured on a TOC-5000A carbon analyzer (Shimadzu, Kyoto, Japan). Gravimetric soil water contents were determined at the same time as the inorganic $\mathrm{N}$ determinations. Inorganic $\mathrm{N}$ data were then used to determine the netnitrification rates by calculating the change in soil inorganic $\mathrm{N}$ concentrations divided by the number of days between sampling.

Nondestructive soil $\mathrm{pH}$ measurements were taken at the surface of the Group 2 soil cores throughout the experiment using a calibrated flat-surface $\mathrm{pH}$ electrode (Broadley-James, Irvine, $\mathrm{CA}$ ). The $\mathrm{CO}_{2}$ flux from the Group 2 soil cores was measured over time using an infrared gas analyzer (EGM-1; PP Systems, Hitchin, UK). This analyzer was placed over the soil core so that it formed a seal with the moist silica flour on the tension table. Each $\mathrm{CO}_{2}$ flux measurement was 2 min in duration.

Statistical analyses were performed using Minitab 14 (Minitab, 2003). Analysis of variance was performed to determine statistical differences among treatments on individual days, following checks to ensure the assumptions underlying the analysis of variance were not violated. Error bars in figures are least significant differences between means at the $5 \%$ level of significance. Linear regression and correlation were performed to determine the relationship between $\mathrm{CO}_{2}$ flux and soil $\mathrm{pH}$.

\section{RESULTS}

\section{Nitrous Oxide and Dinitrogen Gas Production}

The application of DFE alone did not significantly increase the production rate of $\mathrm{N}_{2} \mathrm{O}$ above that of the control (Fig. 1a). However, $\mathrm{N}_{2} \mathrm{O}$ production increased in all the urine-based treatments following treatment application. The maximum $\mathrm{N}_{2} \mathrm{O}$ production rate occurred on Day 2 at $26 \mathrm{ng} \mathrm{g} \mathrm{soil}^{-1} \mathrm{~d}^{-1}$ in the UDFE0 treatment (Fig. 1a). Mean production rates of $\mathrm{N}_{2} \mathrm{O}$ after urine application were rarely significantly higher than those of the control treatment, due to the data's large variability. When the urine-based treatments were compared with one another, $\mathrm{N}_{2} \mathrm{O}$ production rates from the UDFE0 treatment were significantly higher than the urine-only treatment on Day 2, and those from the UDFE1 treatment were higher than the urine-only treatment on Days 1,7 , and $9(p<0.01)$. When integrated over the entire study period the amount of $\mathrm{N}_{2} \mathrm{O}$ produced in the UDFE1 treatment $\left(391 \pm 176[\mathrm{SD}] \mathrm{ng} \mathrm{N}_{2} \mathrm{O}-\mathrm{N}\right.$ g soil $\left.{ }^{-1}\right)$ was significantly higher $(p<0.05)$ than in the control (54 $\pm 96[\mathrm{SD}]$ ng $\mathrm{N}_{2} \mathrm{O}-\mathrm{N} \mathrm{g} \mathrm{soil}{ }^{-1}$ ) but not the urineonly treatment $\left(185 \pm 154\right.$ [SD] ng $\mathrm{N}_{2} \mathrm{O}-\mathrm{N}$ g soil $\left.{ }^{-1}\right)$. The atom $\%{ }^{15} \mathrm{~N}$ enrichments of the $\mathrm{N}_{2} \mathrm{O}$ produced were less than the level of ${ }^{15} \mathrm{~N}$ enrichment in the urine urea $\mathrm{N}$ applied, $\leq 29$ atom $\%{ }^{15} \mathrm{~N}$ (Table 3 ), with no statistically significant differences among treatments $(p \geq 0.08)$.

Following urine application, the production rate of ${ }^{15} \mathrm{~N}$-labeled $\mathrm{N}_{2}$ increased from Day 1 to peak on Day 2 (343 ng $\mathrm{g} \mathrm{soil}^{-1} \mathrm{~d}^{-1}$ ) with no significant differences among ${ }^{15} \mathrm{~N}$-labeled treatments at this time (Fig. 1b).
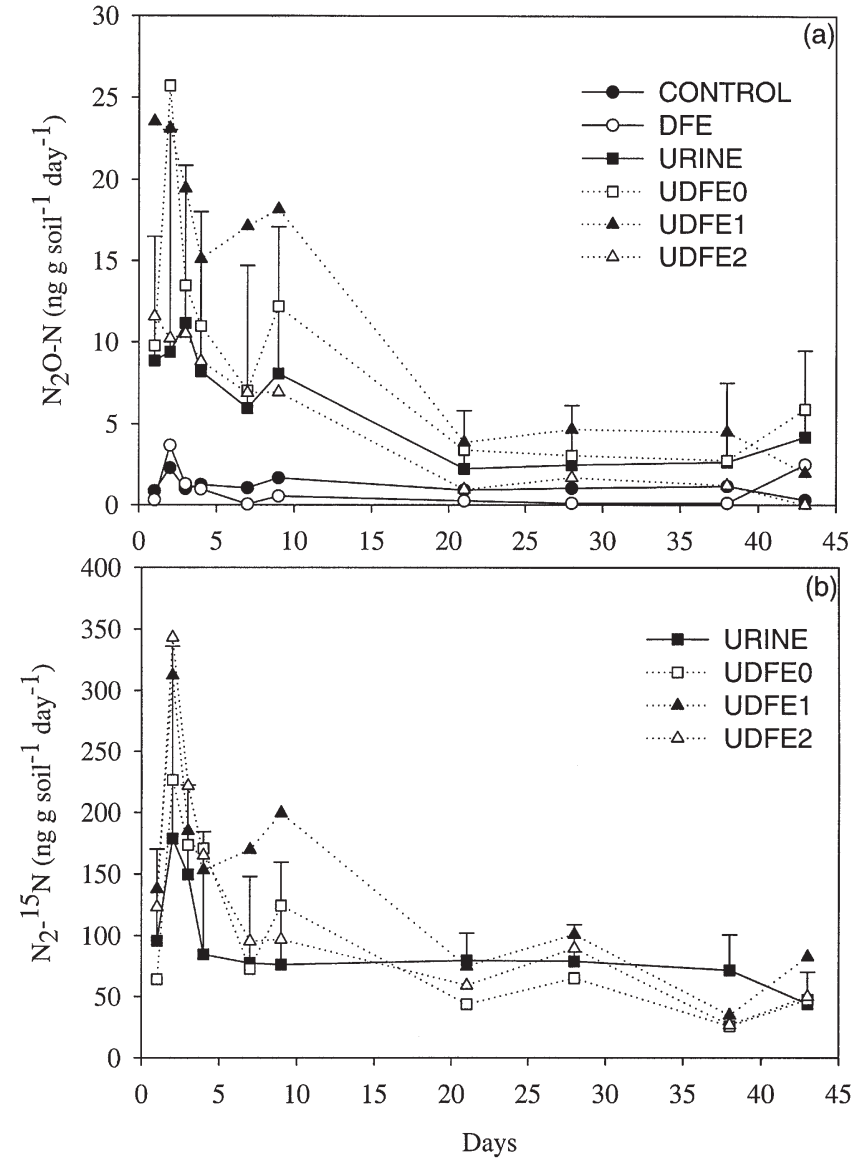

Fig. 1. Fluxes of (a) $\mathrm{N}_{2} \mathrm{O}-\mathrm{N}$ and (b) $\mathrm{N}_{2}-{ }^{15} \mathrm{~N}$ over time. Data points are treatment means $(n=4)$. Error bars associated with the urine treatment are + LSD at $p<0.05$ for treatment comparisons. DFE, dairy farm effluent; UDFE, urine + dairy farm effluent.

However, the production rate of $\mathrm{N}_{2}$ did vary with treatments on Days 7 and 9, when the rate of $\mathrm{N}_{2}$ production in the UDFE1 treatment was higher than that in the urine-only treatment $(p<0.04)$. When integrated over the entire study period the amount of $\mathrm{N}_{2}$ produced in the UDFE1 treatment $\left(4789 \pm 1166[\mathrm{SD}] \mathrm{ng} \mathrm{N}_{2}-\mathrm{N}\right.$ g soil $\left.^{-1}\right)$ was again significantly higher $(p<0.05)$ than in

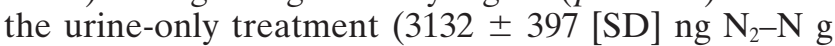
soil $^{-1}$ ). The enrichment of the $\mathrm{N}_{2}$ gas in the headspace reached a maximum of 0.385 atom $\%{ }^{15} \mathrm{~N}$ on Day 2 in the UDFE2 treatment (Table 3).

The ratio of $\mathrm{N}_{2} \mathrm{O}-{ }^{15} \mathrm{~N}$ to $\left(\mathrm{N}_{2} \mathrm{O}-{ }^{15} \mathrm{~N}+\mathrm{N}_{2}-^{15} \mathrm{~N}\right)$ did not differ significantly among the urine-based treatments $(p \geq 0.07)$ on any given sampling occasion. However, the overall mean ratio did vary significantly with sampling time $(p<0.01)$. It was at a maximum between Days 3 to $6[0.21(\mathrm{SD}=0.07)$ to $0.32(\mathrm{SD}=0.09)]$ and $<0.15$ outside this period with a minimum of value of $0.06(\mathrm{SD}=0.02)$.

\section{Inorganic Nitrogen Concentrations and Nitrification Rates}

The soil $\mathrm{NH}_{4}^{+}-\mathrm{N}$ concentrations increased immediately $(p<0.01)$ following urine and UDFE0 treatment applications, peaking on Day 7 at $345 \mu \mathrm{g} \mathrm{NH}_{4}^{+}-\mathrm{N}$ g soil ${ }^{-1}$ 
Table 3. Atom $\%{ }^{15} \mathrm{~N}$ enrichment of $\mathrm{N}_{2} \mathrm{O}$ and $\mathrm{N}_{2}$ fluxes from urine-based treatments.

\begin{tabular}{|c|c|c|c|c|c|c|c|c|c|c|}
\hline \multirow[b]{2}{*}{ Treatment $\dagger$} & \multicolumn{10}{|c|}{ Days since urine application } \\
\hline & 1 & 2 & 3 & 4 & 7 & 9 & 21 & 28 & 38 & 43 \\
\hline \multicolumn{11}{|c|}{ atom $\%{ }^{15} \mathbf{N}$} \\
\hline Urine & 4.7 & 7.2 & 15.9 & 21.1 & 22.0 & 25.2 & 18.9 & 18.9 & 16.9 & 20.1 \\
\hline UDFE0 & 3.6 & 3.6 & 15.9 & 20.9 & 24.0 & 24.5 & 12.8 & 12.8 & 19.3 & 11.8 \\
\hline UDFE1 & 2.5 & 4.5 & 16.4 & 19.6 & 22.0 & 22.5 & 19.5 & 19.5 & 16.0 & 18.2 \\
\hline UDFE2 2 & 5.7 & 13.2 & 24.5 & 27.0 & 29.0 & 27.4 & 19.7 & 19.7 & 15.4 & 20.5 \\
\hline \multirow[t]{2}{*}{ LSD } & 2.6 & 7.9 & 6.7 & 8.3 & 14.3 & 14.4 & 10.2 & 7.9 & 6.0 & 13.0 \\
\hline & NS & NS & NS & NS & NS & NS & NS & NS & NS & NS \\
\hline \multicolumn{11}{|c|}{$\underline{\mathbf{N}_{2}}$} \\
\hline Urine & 0.372 & 0.376 & 0.375 & 0.371 & $\mathbf{0 . 3 7 1}$ & 0.371 & 0.371 & 0.371 & 0.371 & 0.369 \\
\hline UDFE0 & 0.370 & 0.379 & 0.376 & 0.376 & 0.371 & 0.374 & 0.369 & 0.370 & 0.368 & 0.369 \\
\hline UDFE1 & 0.374 & 0.383 & 0.377 & 0.375 & 0.376 & 0.378 & 0.371 & 0.372 & 0.369 & 0.371 \\
\hline & 0.373 & 0.385 & 0.379 & 0.376 & 0.372 & 0.372 & 0.370 & 0.372 & 0.368 & 0.370 \\
\hline \multirow{2}{*}{ LSD $\times 10^{-3}$} & 4 & 8 & 4 & 5 & 4 & 4 & 1 & 2 & 1 & 1 \\
\hline & NS & NS & NS & NS & $*$ & $*$ & $* *$ & NS & * & $*$ \\
\hline
\end{tabular}

* Significant at the 0.05 probability level.

** Significant at the 0.01 probability level.

$\dagger$ DFE, dairy farm effluent; UDFE, urine + dairy farm effluent applied on Days 0, 7, and 14 for treatments UDFE0, UDFE1, and UDFE2, respectively.

in the urine-only treatment (Fig. 2a). Concentrations of soil $\mathrm{NO}_{2}^{-}-\mathrm{N}$ were elevated in the urine and UDFE0 treatments after $7 \mathrm{~d}$, reaching $0.68 \mu \mathrm{g} \mathrm{NO}_{2}^{-}-\mathrm{N}$ g soil ${ }^{-1}$ at this time, but the high variability of the data meant these concentrations were not different from the control and DFE treatments (Fig. 2b). From Day 14 onward soil $\mathrm{NO}_{2}^{-}-\mathrm{N}$ concentrations remained at $<0.14 \mu \mathrm{g} \mathrm{NO}--\mathrm{Ng}$ soil $^{-1}$ but with higher concentrations in the urine treatment than the control on Days 14 and $28(p<0.05)$. Soil $\mathrm{NO}_{3}^{-}-\mathrm{N}$ concentrations increased above those in the control treatment following the addition of urine in both the urine and UDFE0 treatments $(p<0.001)$ peaking at $597 \mu \mathrm{g} \mathrm{NO}_{3}^{-}-\mathrm{N} \mathrm{g}$ soil $^{-1}$ (Fig. 2c). The DFEamended soils and controls did not differ with respect to soil $\mathrm{NO}_{3}^{-}-\mathrm{N}$ concentrations (Fig. 2c).

The net rates of change in soil inorganic $\mathrm{N}$ concentrations were significantly higher $(p<0.01)$ for the urine and UDFE0 treatments than in the nonurine treatments, up until Day 14. After this time there was no difference among treatments in the net rates of change in the soil $\mathrm{NH}_{4}^{+}-\mathrm{N}$ and $\mathrm{NO}_{3}^{-}-\mathrm{N}$ concentrations. Rates of change in soil $\mathrm{NH}_{4}^{+}-\mathrm{N}$ concentrations were negative by Days 7 to 14 , peaking at $-31 \mu \mathrm{g} \mathrm{NH}{ }_{4}^{+}-\mathrm{N} \mathrm{g}$ soil ${ }^{-1} \mathrm{~d}^{-1}$. The maximum net rate of nitrification (i.e., the increase in the soil $\mathrm{NO}_{3}^{-}-\mathrm{N}$ concentrations), $43 \mu \mathrm{g} \mathrm{NO}--\mathrm{Ng} \mathrm{soil}^{-1} \mathrm{~d}^{-1}$, also occurred between 7 and $14 \mathrm{~d}$ in the UDFE0 treatment. The net rate of change in soil $\mathrm{NO}_{3}^{-}-\mathrm{N}$ concentrations had become negative by Day 28 .

\section{Soil Surface pH and Soil Moisture}

Despite the high $\mathrm{pH}$ of the DFE applied, there was no significant difference in the soil surface $\mathrm{pH}$ of the control and DFE treatments (Fig. 3a). Where urine was a treatment constituent, the soil surface $\mathrm{pH}$ increased rapidly to be $>8.0$ following urine application. This was significantly higher than the control and DFE treatments from Day 2 to 10. From Day 11 to 18, there was no significant difference in the soil surface $\mathrm{pH}$ among treatments. After this time the soil surface $\mathrm{pH}$ in the urine treatments declined to be less than the DFE and control treatments with the UDFE0, UDFE1, and UDFE2 treatments hav- ing soil surface $\mathrm{pH}$ values that lay between the values of the urine and control treatments (Fig. 3a). Soil moisture contents at Days 7, 14, 21, 28, and 43, were 76, 78, 78, 76, and $74 \%$ WFPS respectively, all with a standard error of the mean of $2 \%$.

\section{Soil Carbon Dioxide Production Rates and Water-Soluble Carbon}

Before treatment applications, the soil $\mathrm{CO}_{2}$ production rates averaged $150 \mathrm{mg} \mathrm{CO} \mathrm{kg} \mathrm{soil}^{-1} \mathrm{~d}^{-1}$ and did not differ significantly among treatments. When urine was a treatment constituent the $\mathrm{CO}_{2}$ production rate increased $(p<0.01)$ immediately after urine application, with higher $\mathrm{CO}_{2}$ production rates than in either the control or DFE treatments until Day 5 (Fig. 3b). The maximum $\mathrm{CO}_{2}$ production rate was $1046 \mathrm{mg} \mathrm{CO}$ $\mathrm{kg} \mathrm{soil}^{-1} \mathrm{~d}^{-1}$ on Day 2 in the urine-only treatment compared with the control (Fig. 3b). No significant or consistent treatment differences in $\mathrm{CO}_{2}$ production occurred after DFE application on Day 7. Following DFE applications on Day 14, the production rates of $\mathrm{CO}_{2}$ were higher from the control and the DFE treatment than any of the urine-based treatments $(p<0.05)$. After Day $23, \mathrm{CO}_{2}$ production rates were still higher from both the control and DFE treatments, while the rate in the urine-only treatment was the lowest $(p<0.05)$. The $\mathrm{CO}_{2}$ production rates for the DFE and urine treatments were of an interim in value compared with the other treatments (Fig. 3b). When integrated over $10 \mathrm{~d}$ the urine-treated soils (range 3638-3764 $\mathrm{mg} \mathrm{CO}_{2} \mathrm{~kg}$ soil $^{-1}$ ) produced more $\mathrm{CO}_{2}(p<0.01)$ than the control or DFE-treated soil (range 1602-1765 $\mathrm{mg} \mathrm{CO}_{2} \mathrm{~kg}$ soil $^{-1}$ ). However, when integrated over $39 \mathrm{~d}$ the difference among treatments became insignificant with the control soil producing $4401 \pm 712 \mathrm{mg} \mathrm{CO} \mathrm{kg}$ soil $^{-1}$ and the highest-yielding urine-treated soil $5042 \pm 1215 \mathrm{mg} \mathrm{CO}_{2} \mathrm{~kg}$ soil $^{-1}$; errors are standard deviations. Correlation of soil $\mathrm{pH}$ versus $\mathrm{CO}_{2}$ production rate for Days 1 to 43 and Days 10 to 43 were 0.78 and 0.48 respectively $(p<$ $0.001)$. The linear regressions of soil $\mathrm{pH}(x)$ versus $\mathrm{CO}_{2}$ production rate $(y)$ for Days 1 to $43(y=-0.18+0.06 x)$ 

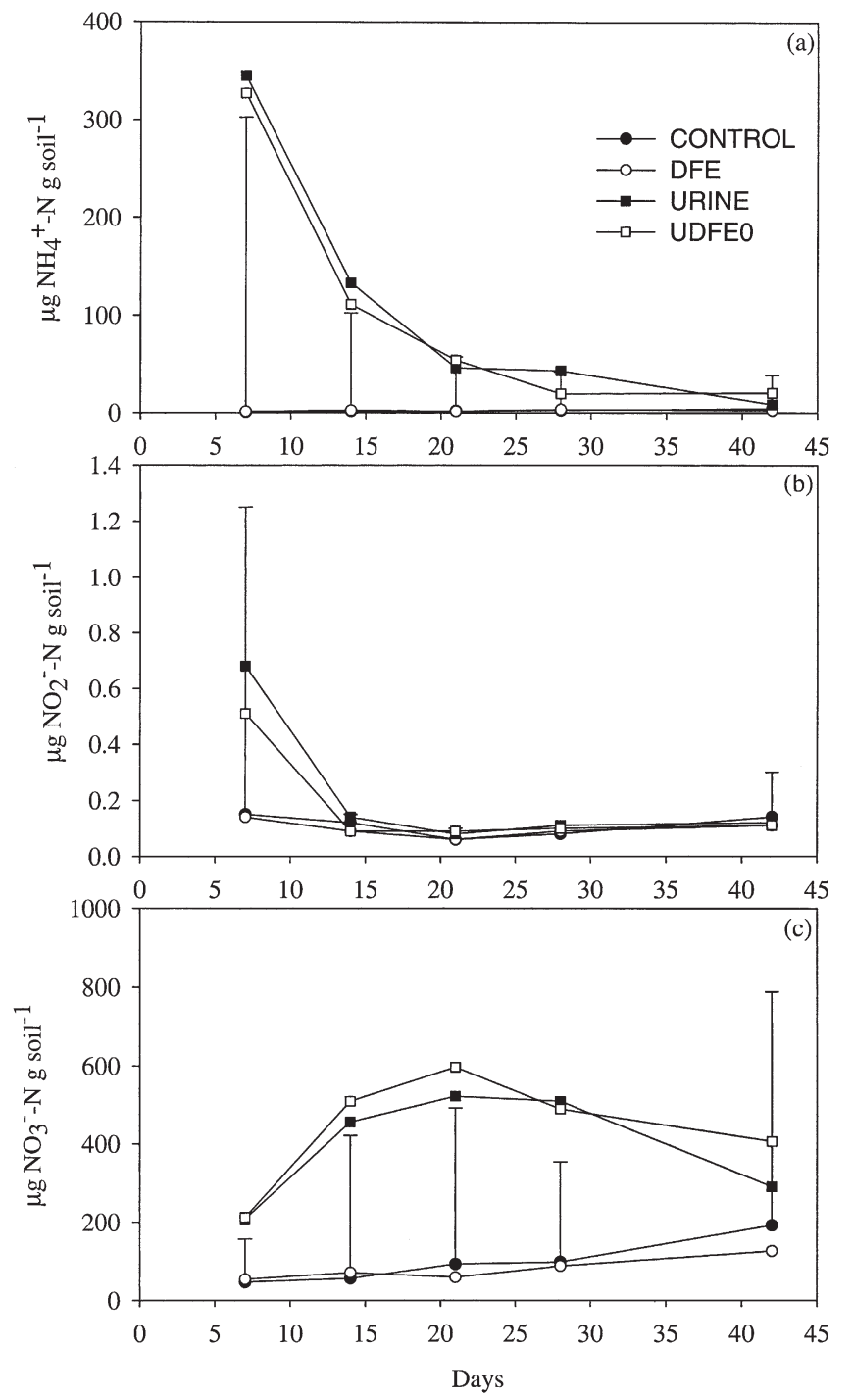

Fig. 2. Changes in soil inorganic $N$ concentrations over time. Data points are treatment means $(n=3)$. Error bars associated with the control treatment are $+\mathbf{L S D}$ at $p<0.05$ for treatment comparisons. Error bars are smaller than symbols between Days 10 to 30. DFE, dairy farm effluent; UDFE, urine + dairy farm effluent.

and Days 10 to $43(y=-0.8+0.18 x)$ were also significant $(p<0.001)$ with $r^{2}$ values accounting for 60.3 and $22.5 \%$ of the variance, respectively.

The application of DFE alone did not significantly change the $\mathrm{CO}_{2}$ production rate compared with the control treatment. However, there was a significant effect of urine application (Table 4) on $\mathrm{CO}_{2}$ production rate. In the urine-based treatments, 61 to $68 \%$ of the total $\mathrm{CO}_{2}$ flux for the 39-d measurement period occurred in the first $10 \mathrm{~d}$. For the control and DFE treatments the corresponding range was 34 to $37 \%$ (Table 4). Assuming all the $\mathrm{C}$ substrates added in the urine evolved as $\mathrm{CO}_{2}$ (i.e., $2526 \mathrm{mg} \mathrm{CO}_{2} \mathrm{~kg}^{-1}$ soil), the treatment effect excess attributable to increased soil microbial activity was $1112 \mathrm{mg} \mathrm{CO} \mathrm{kg} \mathrm{soil}^{-1}$. Dividing the excess $\mathrm{CO}_{2}$ produced by the $\mathrm{CO}_{2}$ produced in the control treatment produced a synthetic urine priming effect of 0.69 .

After $43 \mathrm{~d}$, WSC was dominated by organic C. Inor-
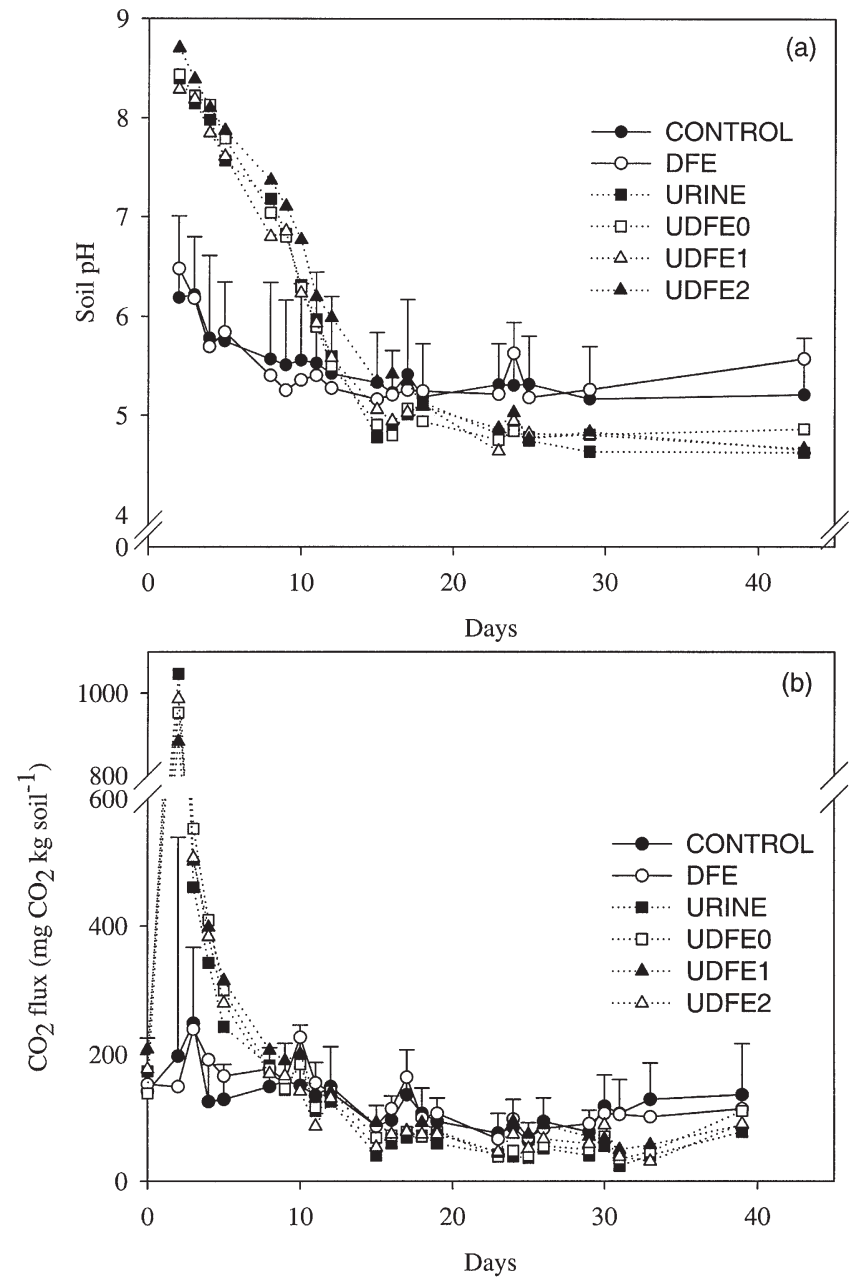

Fig. 3. Changes in (a) soil surface $\mathrm{pH}$ and (b) $\mathrm{CO}_{2}$ flux over time. Data points are treatment means $(n=4)$. Error bars associated with the control treatment are + LSD at $p<0.05$ for treatment comparisons. DFE, dairy farm effluent; UDFE, urine + dairy farm effluent.

ganic WSC was below detection limits. Water-soluble organic carbon (WSOC) in the DFEU0 and DFEU1 treatments averaged $0.18 \mu \mathrm{g}$ WSOC $\mathrm{g} \mathrm{soil}^{-1}$. This concentration was higher $(p<0.01)$ than that of the control, DFE, or urine-based treatments (average $0.07 \mu \mathrm{g}$ WSOC $\mathrm{g}$ soil $^{-1}$ ). Assuming an average WSOC content of $330 \mu \mathrm{g} \mathrm{mL}^{-1}$ in the DFE applied, then three $25-\mathrm{mL}$

Table 4. Cumulative $\mathrm{CO}_{2}$ flux.

\begin{tabular}{lccc}
\hline & & & \multicolumn{2}{c}{$\begin{array}{c}\text { Days 0 to 10 as \% of } \\
\text { Days 0 to 39 }\end{array}$} \\
\hline & Days 0 to 10 & Days 0 to 39 & $\begin{array}{c}\text { Datment } \dagger \\
\text { Control }\end{array}$ \\
\cline { 2 - 4 } mg CO & kg soil $^{-1}$ & 34 \\
DFE & 1602 & 4740 & 37 \\
Urine & 1765 & 4822 & 68 \\
UDFE0 & 3638 & 5375 & 64 \\
UDFE1 & 3721 & 5796 & 61 \\
UDFE2 & 3764 & 6133 & 65 \\
LSD & 3681 & 5650 & 5 \\
& 723 & 1201 & $* *$ \\
\hline
\end{tabular}

* Significant at the 0.05 probability level.

** Significant at the 0.01 probability level.

$\uparrow$ DFE, dairy farm effluent; UDFE, urine + dairy farm effluent applied on Days 0, 7, and 14 for treatments UDFE0, UDFE1, and UDFE2, respectively. 
DFE applications amounted to $80 \mu \mathrm{g}$ WSOC $\mathrm{g}$ soil $^{-1}$, well in excess of the WSOC recovered.

\section{DISCUSSION}

\section{Nitrogenous Gas Production}

Apart from the UDFE0 and UDFE1 treatments the addition of DFE to the urine patch did not affect the $\mathrm{N}_{2} \mathrm{O}$ production rate. Likewise the daily $\mathrm{N}_{2}$ production rate was only affected in the UDFE1 treatment, while the ratio of $\mathrm{N}_{2} \mathrm{O}-{ }^{15} \mathrm{~N}$ to $\left(\mathrm{N}_{2} \mathrm{O}-{ }^{15} \mathrm{~N}+\mathrm{N}_{2}-{ }^{15} \mathrm{~N}\right)$ was not affected. The magnitude and the duration of $\mathrm{N}_{2} \mathrm{O}$ production from the urine-treated soils were consistent with previous work, where comparable soils have received the same rate of urine $\mathrm{N}$ and had similar $\mathrm{pH}$ (Clough et al., 2001, 2004). It was hypothesized that the addition of WSC, in the DFE applications, would enhance heterotrophic microbial processes such as denitrification, since WSC has been shown to be well correlated with denitrification (Burford and Bremner, 1975). The addition of extra $\mathrm{C}$ was also expected to influence the ratio of the $\mathrm{N}_{2} \mathrm{O}$ to $\mathrm{N}_{2}$ produced (Firestone, 1982).

The increases in $\mathrm{N}_{2} \mathrm{O}$ production in the UDFE0 and UDFE1 treatments on Days 2 and 7, respectively, were short lived and relatively small in comparison with the total $\mathrm{N}_{2} \mathrm{O}$ flux at these times. When integrated over the entire study period the UDFE1 treatment produced more $\mathrm{N}_{2} \mathrm{O}$ than the control and had there been increased replication it is possible that a treatment effect may have been seen between the UDFE1 and urine-only treatment. Likewise the UDFE1 treatment produced more $\mathrm{N}_{2}$ than the urine-only treatment. Since the fresh DFE composition was very similar across all application times it is likely that this increase in denitrification in the UDFE1 treatment was due to conditions in the urineaffected soil $1 \mathrm{wk}$ post-urine application. These conditions could have included the relative concentrations of inorganic $\mathrm{N}$ in the soil. The gateway through which $\mathrm{N}_{2} \mathrm{O}$ must be formed is $\mathrm{NO}_{2}^{-}-\mathrm{N}$ and it was at Day 7 that soil $\mathrm{NO}_{2}^{-}-\mathrm{N}$ concentrations were at their highest. Master et al. (2003) showed the significance of soil $\mathrm{NO}_{2}^{-}-\mathrm{N}$ concentrations while measuring $\mathrm{N}_{2} \mathrm{O}$ production from effluent-treated soils. The small increase in $\mathrm{N}_{2}$ production in the UDFE1 treatment was most likely a result of the increased $\mathrm{N}_{2} \mathrm{O}$ production and its further reduction to $\mathrm{N}_{2}$. The lack of significant differences in the ratio of $\mathrm{N}_{2} \mathrm{O}-{ }^{15} \mathrm{~N}$ to $\left(\mathrm{N}_{2} \mathrm{O}-{ }^{15} \mathrm{~N}+\mathrm{N}_{2}-{ }^{15} \mathrm{~N}\right)$ may have been due to added $\mathrm{C}$ sources being unavailable to the denitrifiers, the $\mathrm{C}$ released as a result of urine addition nullifying any potential affect of the added $\mathrm{C}$, or inorganic $\mathrm{N}$ levels determining the ratio of $\mathrm{N}_{2} \mathrm{O}-{ }^{15} \mathrm{~N}$ to $\left(\mathrm{N}_{2} \mathrm{O}-{ }^{15} \mathrm{~N}+\mathrm{N}_{2}-{ }^{15} \mathrm{~N}\right)$ (Firestone et al., 1979).

In general the overall lack of any enhanced $\mathrm{N}_{2} \mathrm{O}$ production or consumption following DFE application to the urine-treated soils may be a consequence of the added DFE substrates ( $\mathrm{C}$ and $\mathrm{N}$ ) being of an insignificant amount when compared with those either supplied in the urine or those substrates released from the soil due to urine addition as discussed below.

Alternatively the general lack of any enhanced $\mathrm{N}_{2} \mathrm{O}$ production or consumption in the DFE plus urine treatments could have been due to the microbial population being influenced by soil chemical factors within the urine patch. It has recently been noted that different denitrifying species in the soil can be promoted or inhibited by the type of treatment applied to the soil. For example Wolsing and Prieme (2004) found that soils treated with mineral fertilizer or cattle manure produced different communities of denitrifying bacteria. Denitrifier community structure can influence $\mathrm{N}_{2} \mathrm{O}$ fluxes (Cavigelli and Robertson, 2000; Munch, 1989). In our study, soil $\mathrm{pH}$ changes over time in the urine-based treatments may have influenced denitrifier function or community composition.

Previous work, at similar soil temperatures to this study, found $\mathrm{N}_{2} \mathrm{O}$ fluxes increased when a mineral soil was treated with DFE (Barton and Schipper, 2001). However, the $\mathrm{N}_{2} \mathrm{O}$ fluxes were only higher in the DFE-treated soils for $3 \mathrm{~h}$ in the autumn and $48 \mathrm{~h}$ in the spring (Barton and Schipper, 2001). Due to our moderate sampling regime any significant $\mathrm{N}_{2} \mathrm{O}$ production would not have been detected in the $3 \mathrm{~h}$ following DFE application. The lack of significant DFE-induced $\mathrm{N}_{2} \mathrm{O}$ production in our study, when compared with Barton and Schipper's (2001) results, may also be a consequence of the higher inorganic $\mathrm{N}$ concentrations in their DFE application, the presence of pasture and thus root mucilage increasing denitrifier activity (Mounier et al., 2004), the differences in soil depth, soil moisture effects, and soil drainage. It would be worthwhile repeating aspects of our study in conjunction with soil wetting and drying cycles and in the presence of pasture species to determine if, over the long term, DFE applications make any difference to urine-induced $\mathrm{N}_{2} \mathrm{O}$ production. Dairy farm effluent, under the conditions of this study, was not a suitable management tool for mitigating $\mathrm{N}_{2} \mathrm{O}$ emissions.

The atom $\%{ }^{15} \mathrm{~N}$ enrichment of the $\mathrm{N}_{2} \mathrm{O}$ produced also indicates that $\mathrm{N}$ other than the ${ }^{15} \mathrm{~N}$-labeled urea $\mathrm{N}$ was contributing to the $\mathrm{N}_{2} \mathrm{O}$ flux. That is, the atom \% ${ }^{15} \mathrm{~N}$ enrichment of the $\mathrm{N}_{2} \mathrm{O}$ produced was less than the level of ${ }^{15} \mathrm{~N}$ enrichment applied, particularly on Days 1 and 2. The hydrolysis of urea raises the soil $\mathrm{pH}$ and solubilizes soil organic matter that can, in turn, lead to significant deamination (Sen and Chalk, 1993). Such an unlabeled source of $\mathrm{N}$ could have provided further $\mathrm{N}$ substrate for the $\mathrm{N}_{2} \mathrm{O}$ production mechanisms. Alternatively other natural abundance $\mathrm{N}$, such as the glycine $\mathrm{N}$ applied in the urine, could have contributed to the substrates utilized by the $\mathrm{N}_{2} \mathrm{O}$ producing mechanisms and contributed to a reduced $\mathrm{N}_{2} \mathrm{O}^{-15} \mathrm{~N}$ enrichment.

\section{Soil Carbon and Priming}

Measured fluxes of $\mathrm{CO}_{2}$ from synthetic urine and urea granules (Lockyer, 1984; Lovell and Jarvis, 1996; Tenuta and Beauchamp, 2000) have been accredited to the chemical reactions involved in urea hydrolysis and the ensuing hydrolysis of the carbonate ions to form $\mathrm{CO}_{2}$ (Sherlock and Goh, 1983). Allowing for such chemical reactions, there was still a release of $\mathrm{CO}_{2}$ from the soil equivalent to $303 \mathrm{mg} \mathrm{C} \mathrm{kg} \mathrm{soil}{ }^{-1}$ over $10 \mathrm{~d}$ as a result of urine 
application. This priming effect has been noted before in urine-treated soils (Clough et al., 2003) and the concept of priming has been reviewed by Kuzyakov et al. (2000). Insoluble organic forms of C, such as feces, were also applied in the DFE and some of this insoluble C may also have been mineralized and become available to microorganisms. It should also be noted that not all of the applied WSC in the DFE would have been readily available to the soil microorganisms (Lundquist et al., 1999). Overall the amount of C applied in the DFE was insignificant in comparison with the $\mathrm{C}$ released during soil priming. The priming effect of urine on $\mathrm{CO}_{2}$ flux lasted $5 \mathrm{~d}$ and was possibly driven by the solubilization of soil organic matter, due to the high soil $\mathrm{pH}$ at this time. Another factor enhancing the priming of soil $\mathrm{C}$ could have been the high inorganic $\mathrm{N}$ concentrations in the soil resulting from urine application. Previous work has shown both positive and sporadic relationships between the amount of available mineral $\mathrm{N}$ and the amount of C mineralized (Chantigny et al., 1999; Liljeroth et al., 1990; Merckx et al., 1987). If priming of soil $\mathrm{C}$ increases the release of $\mathrm{CO}_{2}$ for $5 \mathrm{~d}$ every grazing, and grazing occurs approximately every $3 \mathrm{wk}$ in intensively managed pastures, then priming is a very significant feature of microbial activity in the soil urine patch. Carbon is also returned to pastures due to photoassimilation of $\mathrm{C}$ and has been reported to equal $1320 \mathrm{~kg} \mathrm{C} \mathrm{ha}^{-1} \mathrm{yr}^{-1}$ under a temperate high-fertility dairy pasture (Saggar and Hedley, 2001). Thus the priming effect observed here does not necessarily represent a net loss of $\mathrm{C}$ from the urine patch. In fact other studies in grazed grasslands have found grasslands to be both a source and a sink for $\mathrm{CO}_{2}$ (Leahy et al., 2004; Xu and Baldocchi, 2004). Further work needs to establish the direction of the net flux and the relative magnitudes of the mechanisms responsible (i.e., chemically induced $\mathrm{CO}_{2}$ fluxes from urine patches and the release of $\mathrm{CO}_{2}$ via soil respiration).

The soil surface $\mathrm{pH}$ values in the urine-treated soils declined to be less than that of the control and the DFEtreated soils, after $23 \mathrm{~d}$. Over the same period the $\mathrm{CO}_{2}$ production also declined at a greater rate in the urinetreated soils, when compared with the control and DFE treatments. Assuming all chemical production of $\mathrm{CO}_{2}$ has ceased it is reasonable to assume that this decrease in $\mathrm{CO}_{2}$ production indicates a decrease in soil microbial activity; possibly a result of the urine treatment effect on soil $\mathrm{pH}$. At the same time as $\mathrm{CO}_{2}$ production was decreasing, nitrogenous gas production was also decreasing. This could not be due to a lack of $\mathrm{N}$ substrate since soil $\mathrm{NO}_{3}^{-}-\mathrm{N}$ concentrations were high and soil WFPS conditions were suitable for denitrification (Dobbie and Smith, 2001). This suggests $C$ was becoming limiting at this time or the soil environment was not conducive to high rates of denitrification due to the lowering soil $\mathrm{pH}$.

The close correlation between soil $\mathrm{pH}$ and $\mathrm{CO}_{2}$ production over the first $10 \mathrm{~d}$ is readily explained by chemical processes. Increases in soil $\mathrm{pH}$ following urine application are a result of urea hydrolysis, while the decrease in soil $\mathrm{pH}$ that then follows is a result of hydrogen ions being produced as a consequence of the ammonia volatilization and nitrification processes (Haynes and Sherlock, 1986).

Repeating aspects of this study in the presence of pasture species, in situ, would also overcome any possible artifacts of the laboratory methodology used here. Air drying of soil has been shown to release soil organic C (Merckx et al., 2001). It is theoretically possible that C was released during air-drying of the soils, partially masking the potential effect of DFE carbon on the soil denitrifiers; although equilibration of the soil cores on the water tension tables should have nullified this. Sieving of the soil could potentially also have disrupted microorganism community environments and populations. It has been shown that soil aggregate size can affect the production of $\mathrm{N}_{2} \mathrm{O}$ from applied effluent (Master et al., 2003). Likewise any effects pasture species had on soil bulk density and soil aeration could be considered with in situ studies.

\section{CONCLUSIONS}

In summary the repeated application of DFE to urine patches, commencing at 0,7 , or $14 \mathrm{~d}$ after urine deposition, did not mitigate the $\mathrm{N}_{2} \mathrm{O}$ production rates from the simulated urine patch, or change the ratio of $\mathrm{N}_{2} \mathrm{O}$ to $\mathrm{N}_{2}$ gas fluxes. The application of DFE to urine patches $7 \mathrm{~d}$ after urine deposition increased the total amount of $\mathrm{N}_{2} \mathrm{O}$ produced over the 43-d measurement period when compared with the control soil but not when compared with a urine-only treatment. The application of DFE $7 \mathrm{~d}$ after urine deposition also resulted in small increases in $\mathrm{N}_{2}$ gas production. The amount of WSC applied in the DFE was insignificant compared with the $\mathrm{C}$ released from the soil in the urine patch. This was evident from the measured cumulative $\mathrm{CO}_{2}$ flux, which was greater than the $\mathrm{C}$ inputs in the urine and DFE combined and reasons for this are suggested. Dairy farm effluent, under the conditions of this study, was not a suitable management tool for mitigating $\mathrm{N}_{2} \mathrm{O}$ emissions. However, a field-based study in the presence of pasture plants should be done to verify this. The priming of soil $\mathrm{C}$ in urine patches has implications for the understanding of soil $\mathrm{C}$ processes in grazed pasture ecosystems and the budgeting of $\mathrm{C}$ within these ecosystems.

\section{ACKNOWLEDGMENTS}

The authors acknowledge R. Minchin for technical assistance and the Foundation for Research Science and Technology (FRST) for funding the study.

\section{REFERENCES}

Barton, L., and L.A. Schipper. 2001. Regulation of nitrous oxide emissions from soils irrigated with dairy farm effluent. J. Environ. Qual. 30:1881-1887.

Burford, J.R., and J.M. Bremner. 1975. Relationships between the denitrification capacities of soils and total, water soluble and readily decomposable soil organic matter. Soil Biol. Biochem. 7:389-394.

Cavigelli, M.A., and G.P. Robertson. 2000. The functional significance of denitrifier community composition in a terrestrial ecosystem. Ecology 81:1402-1414.

Chantigny, M.H., D.A. Angers, D. Prévost, R.R. Simard, and F.P. Chalifour. 1999. Dynamics of soluble organic C and C mineraliza- 
tion in cultivated soils with varying $\mathrm{N}$ fertilization. Soil Biol. Biochem. 31:543-550.

Clough, T.J., F.M. Kelliher, R.R. Sherlock, and C.D. Ford. 2004. Lime and soil moisture effects on nitrous oxide emissions from a urine patch soil. Soil Sci. Soc. Am. J. 68:1600-1609.

Clough, T.J., R.R. Sherlock, K.C. Cameron, R.J. Stevens, R.J. Laughlin, and C. Muller. 2001. Resolution of the ${ }^{15} \mathrm{~N}$ balance enigma? Aust. J. Soil Res. 39:1419-1431.

Clough, T.J., R.R. Sherlock, and F.M. Kelliher. 2003. Can liming mitigate $\mathrm{N}_{2} \mathrm{O}$ fluxes from a urine-amended soil? Aust. J. Soil Res. 41:439-457.

Crutzen, P.J. 1981. Atmospheric chemical processes of the oxides of nitrogen, including nitrous oxide. p. 17-44. In C.C. Delwiche (ed.) Denitrification, nitrification and atmospheric nitrous oxide. John Wiley \& Sons, New York.

Di, H.J., and K.C. Cameron. 2004. Effects of the nitrification inhibitor dicyandiamide on potassium, magnesium and calcium leaching in grazed grassland. Soil Use Manage. 20:2-7.

Dobbie, K., and K.A. Smith. 2001. The effects of temperature, waterfilled pore space and land use on $\mathrm{N}_{2} \mathrm{O}$ emissions from an imperfectly drained gleysol. Eur. J. Soil Sci. 53:667-673.

Duxbury, J.M., L.A. Harper, and A.R. Mosier. 1993. Contributions of agroecosystems to global climate change. p. 1-18. In L.A. Harper et al. (ed.) Agricultural ecosystem effects on trace gases and global climate change. Spec. Publ. 55. ASA, Madison, WI.

Firestone, M.K. 1982. Biological denitrification. p. 289-326. In F.J. Stevenson (ed.) Nitrogen in agricultural soils. Agron. Mongr. 22. ASA and SSSA, Madison, WI.

Firestone, M.K., M.S. Smith, R.B. Firestone, and J.M. Tiedje. 1979. The influence of nitrate, nitrite, and oxygen on the consumption of the gaseous products of denitrification in soil. Soil Sci. Soc. Am. J. 43:1140-1144.

Food and Agriculture Organization of the United Nations. 2001 Global estimates of gaseous emissions of $\mathrm{NH}_{3}, \mathrm{NO}$ and $\mathrm{N}_{2} \mathrm{O}$ from agricultural land. FAO, Rome.

Fraser, P.M., K.C. Cameron, and R.R. Sherlock. 1994. Lysimeter studies of the fate of nitrogen in animal urine returns to irrigated pasture. Eur. J. Soil Sci. 4:439-447.

Haynes, R.J., and R.R. Sherlock. 1986. Gaseous losses of nitrogen. p. 242-302. In R.J. Haynes (ed.) Nitrogen in plant-soil systems. Academic Press, New York.

Kuzyakov, Y., J.K. Friedal, and K. Stahr. 2000. Review of mechanisms and quantification of priming effects. Soil Biol. Biochem. 32: $1485-1498$.

Leahy, P., G. Kiely, and T.M. Scanlon. 2004. Managed grasslands: A greenhouse gas sink or source? Geophys. Res. Lett. 31:L20507.

Liljeroth, E., J.A. Van Veen, and H.J. Miller. 1990. Assimilate translocation to the rhizosphere of two wheat lines and subsequent utilization by rhizosphere microorganisms at two soil nitrogen concentrations. Soil Biol. Biochem. 22:1015-1021.
Lockyer, D.R. 1984. A system for measurement in the field of losses of ammonia through volatilization. J. Sci. Food Agric. 35:837-848.

Lovell, R.D., and S. Jarvis. 1996. Effects of urine on soil microbial biomass, methanogenesis, nitrification and denitrification in grassland soils. Plant Soil 151:127-138.

Lundquist, E.J., L.E. Jackson, and K.M. Scow. 1999. Wet-dry cycles affect dissolved organic carbon in two California agricultural soils. Soil Biol. Biochem. 31:1031-1038.

Master, Y., R.J. Laughlin, U. Shavit, R.J. Stevens, and A. Shaviv. 2003. Gaseous nitrogen emissions and mineral nitrogen transformations as affected by reclaimed effluent application. J. Environ. Qual. 32:1204-1211.

Merckx, R., K. Brans, and E. Smolders. 2001. Decomposition of dissolved organic carbon after soil drying and rewetting as an indicator of metal toxicity in soils. Soil Biol. Biochem. 33:235-240.

Merckx, R., A. Dijkstra, A. Den Hartog, and J.A. Van Veen. 1987. Production of root derived material and associated microbial growth in soil at different nutrient levels. Biol. Fertil. Soils 5: 126-132.

Minitab. 2003. Minitab 14. Minitab, State College, PA.

Mounier, E., S. Hallet, D. Cheneby, E. Benizri, Y. Gruet, C. Nguyen, S. Piutti, C. Robin, S. Slezack-Deschaumes, F. Martin-Laurent, J. Germon, and L. Philippot. 2004. Influence of maize mucilage on the diversity and activity of the denitrifying community. Environ. Microbiol. 6:301-312.

Munch, J.C. 1989. Organism specific denitrification in samples of an Udifluvent with different nitrate concentrations. Z. Pflanzenernaehr. Bodenkd. 152:395-400.

Saggar, S., and C.B. Hedley. 2001. Estimating seasonal and annual carbon inputs, and root decomposition rates in a temperate pasture following ${ }^{14} \mathrm{C}$ pulse labelling. Plant Soil 236:91-103.

Sen, S., and P.M. Chalk. 1993. Chemical interactions between soil $\mathrm{N}$ and alkaline-hydrolysing N fertilizers. Fert. Res. 36:239-248.

Sherlock, R.R., and K.M. Goh. 1983. Initial emission of nitrous oxide from sheep urine applied to soil. Soil Biol. Biochem. 31:1491-1501.

Soil Survey Staff. 1998. Keys to soil taxonomy. 8th ed. U.S. Gov. Print. Office, Washington, DC.

Stevens, R.J., R.J. Laughlin, G.J. Atkins, and S.J. Prosser. 1993. Automated determination of nitrogen-15-labeled dinitrogen and nitrous oxide by mass spectrometry. Soil Sci. Soc. Am. J. 57:981-988.

Tenuta, M., and E.G. Beauchamp. 2000. Nitrous oxide production from urea granules of different sizes. J. Environ. Qual. 29:1408-1413.

Wolsing, M., and A. Prieme. 2004. Observation of high seasonal variation in community structure of denitrifying bacteria in arable soil receiving artificial fertilizer and cattle manure by determining T-RFLP of nir gene fragments. FEMS Microbiol. Ecol. 48:261-271.

Xu, L., and D.D. Baldocchi. 2004. Seasonal variation in carbon dioxide exchange over a Mediterranean annual grassland in California. Agric. For. Meteorol. 1232:79-96. 